\title{
Zmienne losy sieci osadniczej regionu mazowieckiego, w tym Obszaru Metropolitalnego Warszawy
}

\section{Mieczysław Kochanowski, Katarzyna Donimirska}

\section{STRESZCZENIE}

Rozwój gospodarczy stolicy skutkuje jej rozwojem przestrzennym. Charakter tego rozwoju nie jest prawidłowy, gdyż na jej peryferiach i poza jej granicami rozciąga się strefa aglomeracji nie objęta planową urbanizacją. Rozrost aglomeracji bez wspólnego planu stanowi zagrożenie dla tożsamości małych miast w niej zagłębionych. Następnym wielkim zagrożeniem jest niedorozwój szynowego zintegrowanego transportu publicznego spajającego Warszawę i aglomerację, szczególnie w jej południowej części. Aby zahamować proces rozlewania się aglomeracji wyznaczenie zielonego pierścienia wokół aglomeracji Warszawy mogłoby ograniczyć wciskanie się zabudowy w piękny krajobraz i urealnić koncepcję wzajemnej wymiany usług między mieszkańcami Warszawy a mieszkańcami sąsiednich gmin. Szansę dla realizacji tej koncepcji stanowi bogaty zasób atrakcyjnych terenów przyrodniczych pod Warszawą i pięknie odnowionych centrów zabytkowych miasteczek dla turystyki kulturowej i rekreacji.

Słowa kluczowe: region mazowiecki, Obszar Metropolitalny Warszawy, sieć osadnicza, suburbanizacja, transport szynowy, obwodnice drogowe, wizerunek miast, dziedzictwo kulturowe i rewitalizacja, środowisko przyrodnicze

\section{Warszawa a jej region}

Relacje między Warszawa, wielką metropolią a jej otoczeniem, czy nazwiemy je strefą podmiejska, obszarem metropolitalnym czy po prostu Mazowszem, mają za sobą bogatą historię. Etapami tej historii są: okres przed II wojną światową i przedwojenny dystans nowego mieszczaństwa stolicy, powojenne uprzedzenia ocalałych warszawiaków do przybyszów z okolicznych miast i miasteczek, którzy staną się podstawą nowej społeczności nowej Warszawy, a także współczesne procesy żywiołowej, żeby nie powiedzieć dzikiej dezurbanizacji, do której można by odnieść używane powszechnie słowo sprawl. Nam tu chodzi o funkcjonalny i przestrzenny wymiar tych zjawiski procesów. Zjawiska dezurbanizacji i rozrastania się stref podmiejskich wielkich metropolii nie są w Europie czymś nowym, a różnią się od siebie cechami wynikającymi zarówno z lokalnych uwarunkowań społecznoekonomicznych, jak i kulturowych. Nie inaczej jest w przypadku Warszawy, gdzie silniej zaważył czynnik przemian historycznych i politycznych.

Godny uwagi jest fakt, że pierwszym poważnym opracowaniem planistycznym, z którym urbanistyka polska już kilkanaście lat po odzyskaniu niepodległości wkroczyła na światowe salony, była sławna koncepcja Warszawa Funkcjonalna Szymona Syrkusa i Jana 


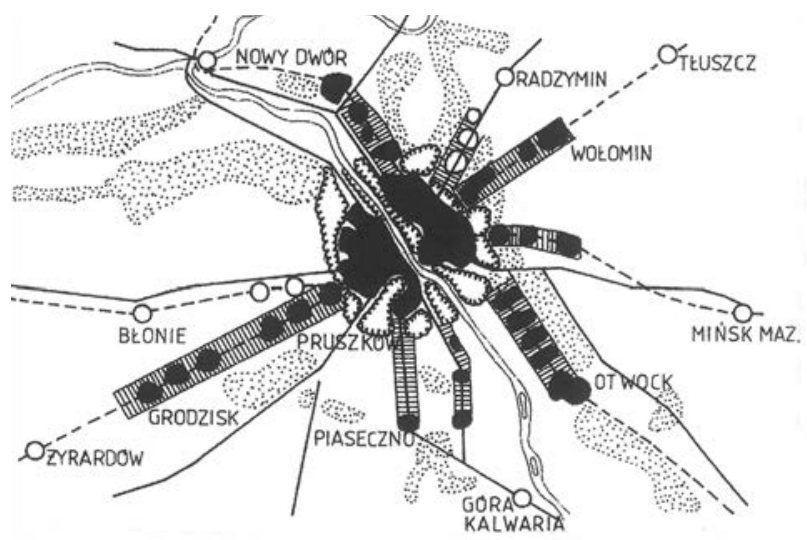

Ryc. 1. Warszawa Funkcjonalna wg Jana O. Chmielewskiego i Szymona Syrkusa, 1934 r. Źródło: URBANISTA, 12, 2003 r.
Chmielewskiego, przedstawiona w 1934 r. na kongresie CIAM i wysoko tam oceniona. W koncepcji tej dostrzec można zamysł głębszego zintegrowania Warszawy z jej otoczeniem. Zasięg Warszawy Funkcjonalnej, mimo swego teoretycznego charakteru i różnic wynikłych z realiów upływającego czasu, jest zbliżony do zasięgu dzisiejszego Obszaru Metropolitalnego Warszawy (choć nieco ograniczony przestrzennie), co jest godne uwagi jako podkreślenie trwałości istniejącego układu osad-

niczego w formowaniu się nowych rozwiązań przestrzennych, w nowych przecież realiach. Wielopasmowy układ Warszawy Funkcjonalnej zdeterminowany jest w znacznej mierze przez ówczesne realia komunikacyjne - samochód osobowy był przedmiotem luksusu i nie mógł rozwiązywać masowych dojazdów do metropolii. Wówczas skuteczna mogła być tylko komunikacja kolejowa, a ta narzucała właśnie koncepcje pasmowo-węzłowe (ryc. 1).

Trudno ocenić czy ta teoretyczna, nowoczesna i funkcjonalna koncepcja wytyczyłaby wyraziście kierunki urbanizacji otoczenia Warszawy. Nadchodząca wojna i jej skutki odsunęły na dłuższy czas przedwojenne koncepcje. Decydujące stały się tu potrzeby szybkiej odbudowy zburzonej metropolii. Żyjące swoim życiem suburbia rozwijały się żywiołowo i tak będzie jeszcze trwało przez długie lata.

\section{Procesy suburbanizacji}

Suburbanizacja w regionach otaczających polskie metropolie rozwinęła się intensywnie po transformacji ustrojowej, gdy wygasły już procesy budowy wielkich skoncentrowanych osiedli mieszkaniowych w latach 70. XX w. Nowe warunki ustrojowe otworzyły nowe perspektywy - także przed wyobraźnią mieszkańców miast. Takie motywy jak prestiżowe aspekty konsumpcji, ujawniające się w posiadaniu własnego domu i dobrej marki samochodu intensyfikowały wędrówkę na peryferia. Drugi motyw - to poszukiwanie kontaktu z naturą przez znużonych miastem, bogacących się mieszkańców miast. Opisane zmiany kulturowe spotkały się z nowymi możliwościami realizacji, gdy znacznie wzrosła dostępność indywidualnego środka transportu, jakim jest samochód osobowy.

Omawiane, występujące równolegle zjawiska doprowadziły do dominacji określonych form suburbanizacji - odmiennych np. od przewidywanych w modelu Syrkusa i Chmielewskiego. Przybrały one postać amorficznych, rozlewających się stref, na ogół słabo 
związanych z istniejącą siecią osadniczą. Początkowo skala i charakter omawianego zjawiska nie budziły powszechnego zaniepokojenia. Przełomem okazało się opracowanie z 2011 r. zespołu pod kierownictwem Jacka Kozińskiego dotyczące gminy Lesznowola [Gazeta Wyborcza 2011]. Wykazano w nim, że polityka przestrzenna gmin otaczających metropolie, polegająca na wydzieleniu bez opamiętania obszarów pod nową zabudowę dla migrujących mieszczan była absurdalna i niebezpieczna. Za cenę doraźnych korzyści (sprzedaż gruntów, powiększanie liczby mieszkańców płacących podatki) gminy mogą wpadać w groźne pułapki. Polegają one m.in. na kosztach budowy infrastruktury dla wybitnie ekstensywnie wykorzystywanych terenów oraz kosztach wykupu przez gminę terenu pod drogi lokalne. Natomiast, wg różnych szacunków (planów i studiów), w polskich gminach wyznaczono już obszary pod nową zabudowę, która mogłaby pomieścić od 80 do $200 \mathrm{mln}$ nowych mieszkańców.

Nasza polityka planistyczna różni się jaskrawo, np. od niemieckiej, gdzie wyznacza się wg precyzyjnie określonych potrzeb - ograniczone tereny pod zabudowę, uzbraja je i dopiero wtedy rozwija się tam osadnictwo. Wydaje się, że czas najwyższy zacząć czerpać z tych wzorów. Obecny brak odpowiednich reakcji na anarchiczną masową suburbanizację może wywołać, prócz opisanych doraźnych - także długofalowe skutki, polegające głównie na ubytku mieszkańców miast - tak metropolii, jak i ośrodków regionalnych. Obniżony potencjał demograficzny polskich miast (Warszawa jest tu jednym z wyjątków - jako atrakcyjny cel migracji z całego kraju) to niebezpieczny prognostyk, a tkanka miejska pozbawiona mieszkańców ulega wynaturzeniu.

Tak więc suburbanizacją w Polsce w decydującym stopniu rządzi prywatny samochód. Samochód oraz głęboko odczuwana potrzeba prestiżu u ludzi, którzy osiedlają się poza zwartymi i intensywnie zabudowanymi miastami. Tęsknota za przyroda, pięknym krajobrazem i spokojem - chociaż to one wymieniane są na czele listy powodów opuszczania miast - robią wrażenie drugorzędnych. Świadczy o tym chociażby standard i architektura nowych siedzib. Samochód zaś decyduje o strukturze przestrzennej obszarów suburbanizacji, o tym, że także w odniesieniu do nich używa się amerykańskiego określenia sprawl - rozpełzanie się. Nie bez powodu. Amerykańskie olbrzymie przedmieścia pokryte standardową jednorodzinną zabudową (american dream) są częścią kultury samochodowej. Bez samochodu nie mogłyby istnieć, choć są one przyczyną wielu dolegliwych problemów trapiących amerykańskie miasta. Wprowadzenie tam wydajnej, masowej komunikacji szynowej praktycznie nie wchodzi w grę. Niska gęstość zaludnienia, mimo wielkości tych przedmieść, przesądza o nierentowności takich rozwiązań. Pozostaje samochód, a ten skutecznie utrwala taki model suburbiów.

Inaczej jest w Japonii. Przybysz z Europy znalazłszy się w Tokio jest zdziwiony, że w centrum 30 milionowej stolicy Japonii - największego na świecie producenta samochodów, ulice wcale nie są zatłoczone. Rzecz się wyjaśnia po zejściu do podziemnego, wielopoziomowego systemu komunikacyjnego - metra i rozmaitych kolei dojazdowych, łączących całą ogromną metropolię. 
To są oczywiście przypadki ekstremalne. Na świecie wiele metropolii stosuje rozwiązania, uwzględniając lokalne warunki i lokalne pomyłki, stąd trudno o jakiekolwiek oceny uniwersalne. Warto jednak zdawać sobie sprawę, że przyjęte rozwiązania decydować mogą o szerszej problematyce niż sama sprawność komunikacyjnych połączeń centrum metropolii z peryferiami.

\section{Rozmieszczenie sieci osadniczej Mazowsza}

Policentryczność sieci osadniczej regionu mazowieckiego uważana jest za dużą wartość województwa, dotyczy jednakże tylko rozmieszczenia ośrodków oddalonych od Warszawy. Miasta uznane za subregionalne (Radom, Płock, Siedlce, Ostrołęka, Ciechanów) są regularnie i stosunkowo rzadko rozmieszczone w przestrzeni Mazowsza, z tym, że dwa pierwsze skalą i w związku z tym możliwościami gospodarczymi przeważają nad pozostałymi. Mniejsze miasta pełnią funkcje obsługi lokalnej lub ponadlokalnej (naukową kulturalna, rekreacyjną).

Miasta położone bliżej Warszawy, przy tzw. Wielkiej Obwodnicy Warszawy sytuowane są na tyle swobodnie, że dzięki otoczeniu przyrodniczemu istnieje możliwość ich wyodrębnienia z aglomeracji. Usytuowanie tych miast stanowi granicę policentryczności sieci osadniczej. Bliżej jądra regionu jest już monocentryczna Warszawa ze swoją aglomeracją.

Miasta i miejscowości blisko Warszawy, zanurzone w magmie metropolitalnej, coraz bardziej zlewają się ze sobąi w rezultacie trudno jest mówić o policentryczności sieci wewnątrz obszaru metropolitalnego, czemu sprzyja zatarcie granic miast, łącznie z Warszawą.

\section{Przedsiębiorczość lokalna}

Bliskość Warszawy nie jest jedynym stymulatorem rozwoju miejscowości. Oprócz dogodnego transportu i infrastruktury istnieją jeszcze stymulatory miękkie, takie jak przedsiębiorczość lokalna, uwarunkowania wewnętrzne, m.in., dbałość o swoje miasto i jego wizerunek, stwarzanie dobrych, zachęcających warunków, które mogą przyciągać inwestorów i różnego rodzaju fachowe kadry.

Przedsiębiorstwa wysokich technologii, zwane lokomotywami gospodarczymi, znajdują się m.in. w Mławie, Żyrardowie i Radomiu. Lokalne ośrodki Mazowsza, np. Pułtusk, Kozienice, Otwock, Pruszków, Żyrardów mają cztery lub więcej przedsiębiorstw lokomotyw rozwoju. W pierwszej pięćdziesiątce miast (w skali kraju) o najwyższym średnim zatrudnieniu w lokomotywach mają niektóre miasta oddalone od Warszawy, takie jak Sokołów Podlaski, Wyszków, Ostrów Mazowiecka, Garwolin, Grójec oraz bliskie Warszawy, jak Piaseczno, Nowy Dwór Mazowiecki [Szewczuk 2016].

Największym zagrożeniem dla regionu mazowieckiego są najwyższe w kraju dysproporcje poziomu gospodarczego między poszczególnymi miastami, powiatami i gminami. Najniższy rozwój mają powiaty ostrołęcki, ciechanowski i siedlecki. Są to powiaty rolnicze o niezbyt korzystnych warunkach przyrodniczych. Stolice tych powiatów to miasta oddalone od Warszawy, tracące mieszkańców. Tradycją tych miast była obsługa rolnictwa 


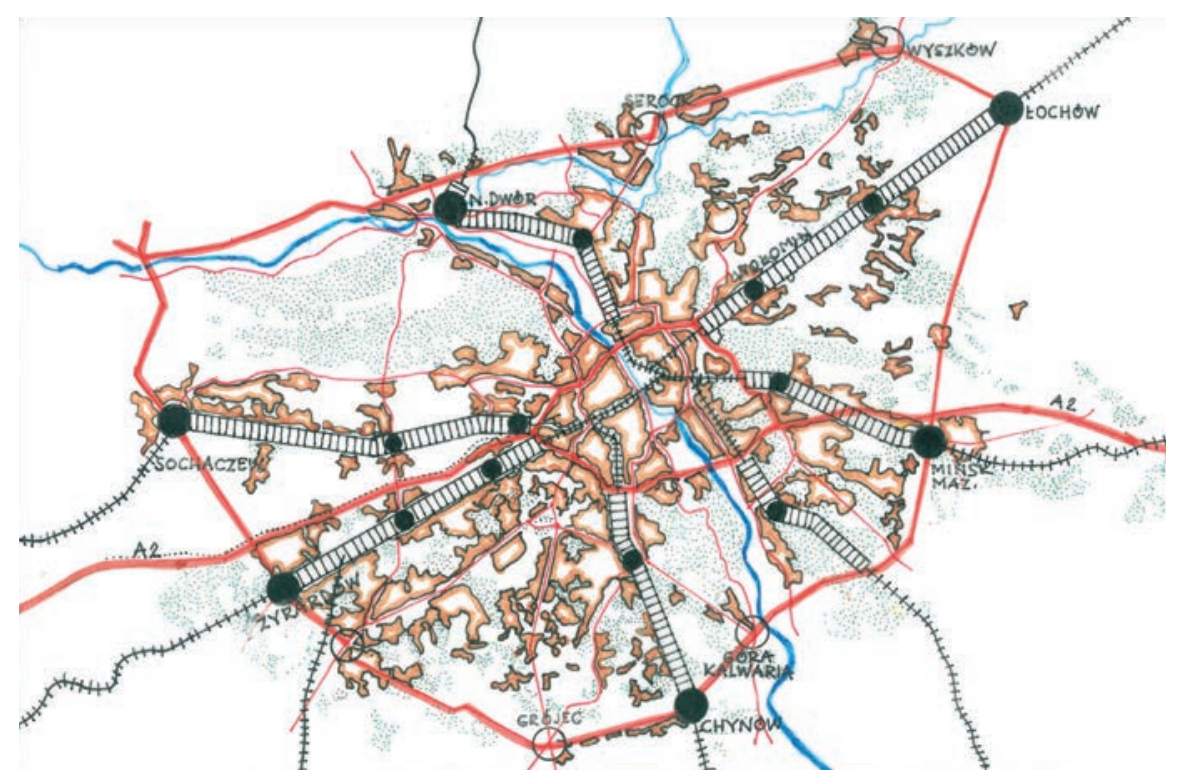

Ryc. 2. Sieć osadnicza w Obszarze Metropolitalnym Warszawy

Źródło: opracowanie własne, autorka Katarzyna Donimirska

przez rzemiosło i handel. Miasta, które były stolicami województw, po utracie tych ważnych funkcji do dziś nie potrafiły znaleźć pomysłu na własny rozwój, choć są także odmienne przykłady.

W wyznaczonym Obszarze Metropolitalnym Warszawy, w promieniu ok. $50 \mathrm{~km}$ od Warszawy znajdują się ośrodki lokalne, w których udział przedsiębiorstw high-tech należy do najwyższych w kraju. Uważa się, że jest to skutek m.in. gospodarczej suburbanizacji - wyprowadzania się przedsiębiorstw, zwłaszcza mikrofirm na obrzeża Warszawy lub lokalizowania się nowych w strefie codziennych dojazdów (ryc. 2).

Miasta znajdujące się na szlaku zachodnim, o największych szansach rozwoju gospodarczego, to miasta o tradycjach przemysłowych - Grodzisk i Żyrardów. W okresie międzywojennym znaczący przemysł znajdował się w miejscowościach bliżej Warszawy (Pruszków, Ursus). Dziś, te miasta zanurzone w aglomeracji, pozbyły się funkcji przemysłowej na rzecz wielkich obiektów handlowych obsługujących stolicę.

\section{Transport szynowy}

Polityka zorientowana na rozwój transportu szynowego zawiera szereg mechanizmów prowadzących do intensyfikacji i uporządkowania układu zabudowy mieszkaniowej i usługowej w rejonie przystanków kolei, metra i tramwaju. Zorientowanie na transport szynowy wpływa na rozwój subcentrów wokół węzłów i korytarzy transportu zbiorowego. 
Transport szynowy, jako główny instrument rozwoju regionu mazowieckiego, w tym aglomeracji warszawskiej, był rozwijany w wieku XIX i XX. Obraz zasięgu komunikacji kolejowej różnego rodzaju form, od kolei do wąskotorowych kolejek dojazdowych, w okresie przed II wojną światową był znacznie bogatszy od obecnego. Zlikwidowane zostały następujące połączenia wąskotorowe: do Wilanowa i Piaseczna, do Góry Kalwarii i Grójca, do Jabłonny i Wawra, do Marek i Radzymina. Dziś wspomina się o tym z żalem, gdyż chłonność transportu drogowego nie może równać się z szynowym, a teren wykupiony pod tory kolejowe został roztrwoniony. Niedorozwój sieci kolei dojazdowych w paśmie południowym lewobrzeżnej Warszawy został zauważony $\mathrm{w}$ opracowaniu studialnym planistycznym OMW [MBPR 2010], w którym m.in. istnieje postulat, aby rozbudować Warszawską Kolej Dojazdową o nową linię do Janek. A przecież na Jankach nie kończy się obszar metropolitalny, z którego i do którego wiele osób udaje się z i do Warszawy codziennie. Zakres rozwoju konieczny do uzupełnienia powinien opierać się o istniejącą obwodnicę drogowa, trasę nr 50, zwaną Wielką Obwodnicą Warszawy i następnie trasę nr 48 zwaną Wielką Obwodnicą Mazowsza. Drugim pasmem rozwojowym, kompletnie niedoinwestowanym w sieć transportu szynowego dojazdowego, jest ciąg wzdłuż parku kampinoskiego, równoległy do drogi wojewódzkiej 580, a następnie skręcający do obwodowej 50 .

Wyjątkowym, w układzie osadniczym Mazowsza i kraju, jest najlepiej doinwestowane pasmo rozwoju w kierunku zachodnim. Jego osią jest szlak Kolei Warszawsko-Wiedeńskiej i osobno Warszawskiej Kolei Dojazdowej z historycznymi założeniami przestrzennymi miast ogrodów (Komorów, Milanówek, Podkowa Leśna). Wystarczy powiedzieć, że najwięcej dojeżdżających do pracy $\mathrm{w}$ Warszawie to pasażerowie $\mathrm{z}$ pasma drogowo-kolejowego kierunku zachodniego, najlepiej skomunikowanego ze stolicą. Historyczne znaczenie tego szlaku komunikacyjnego wzmocnione zostało w ostatnim czasie nowym założeniem drogowym autostrady drogowej A2, z węzłem drogowym Konotopa, rozdzielającym obwodnice na terenie Warszawy na południową i północną. Ponadto na szlaku znajdzie się projektowany tor szybkiej kolei z Warszawy na zachód Europy. Zapowiadana lokalizacja lotniska w okolicy Grodziska Mazowieckiego wykorzystywać będzie istniejące ważne połączenia kolejowe i drogowe oraz projektowane koleje wielkich prędkości. Drugim ważnym kierunkiem jest tzw. Linia Otwocka, trzecim trasa do Tłuszcza przez Wołomin, czwartym do Legionowa przez Choszczówkę.

Niedorozwój szynowego zintegrowanego transportu publicznego spajającego Warszawę i aglomerację jest wielkim zagrożeniem dla wszechstronnego rozwoju osadnictwa, szczególnie w jej południowej części. Najpilniejsze zadanie to wydłużenie warszawskich linii tramwajowych poza granice stolicy (np. pętla tramwajowa na południowym krańcu ulicy Puławskiej znajduje się tam, gdzie usytuowano ją przed II wojną światową przy wyścigach konnych zamiast dużo dalej na południe, np. w Piasecznie). Przywrócenie gęstości sieci podmiejskich lekkich linii transportu szynowego, renowacja stacji kolejowych i terenów wokół nich wzmocni zintegrowanie przystanków kolejowych z przestrzenią ośrodka osadniczego, nastąpi wzbogacenie tych miejsc o funkcje usługowe, handel, 
kulturę itp. Pasażerów odstręcza od kolei i w ogóle publicznego transportu konieczność pokonywania barier przestrzennych $\mathrm{w}$ postaci schodów, kładek nad torami itp. Ponadto przystanki kolejowe $\mathrm{w}$ miastach są najczęściej położone $\mathrm{w}$ strefie zaniedbania miejskiego bez P+R. Przekraczanie torów kolejowych na terenie OMW odbywa się w wielu miejscach z zagrożeniem bezpieczeństwa.

Integracja przystanków kolejowych linii dojazdowych z tramwajowymi i metra to ogromne wyzwanie przed planistami. Obecnie planowane końcowe przystanki II linii metra nie są zintegrowane z przystankami kolejowymi na liniach dojazdowych. A wystarczyłoby wziąć przykład z ROR okręgu paryskiego.

\section{Drogowe obwodnice Mazowsza i Warszawy}

Zadaniem trasy Wielkiej Obwodnicy Mazowsza jest usprawnienie ruchu tranzytowego i lokalnego oraz odciążenie centrów miast od uciążliwości związanych z ruchem poprzez budowę obwodnic miast. Uzasadnieniem działań modernizacyjnych na istniejącej obwodnicy jest podniesienie atrakcyjności obszarów pozametropolitalnych województwa mazowieckiego. Jej przebieg wychodzi poza zakres powierzchni województwa. Ważne miasta mazowieckie na trasie jej przebiegu to Ciechanów, Maków Mazowiecki, Ostrów Mazowiecka, Sokołów Podlaski, Siedlce, Radom, Gostynin i Płock. Promienisty kształt podstawowego drogowego układu komunikacyjnego Mazowsza jest sukcesywnie uzupełniany o system połączeń obwodowych, zwiększający spójność przestrzeni na peryferiach województwa. Cała WOM ma mieć klasę drogi głównej ruchu przyspieszonego.

Barierą dla realizacji inwestycji jest przeświadczenie decydentów, poparte zresztą badaniami, o braku potrzeb w zakresie powiązań komunikacyjnych między miastami subregionalnymi - ośrodkami powiatowymi. Wykazuje się natomiast $\mathrm{w}$ badaniach jedynie potrzebę powiązań miast ze swym najbliższym otoczeniem oraz z Warszawą. Przeczy to idei rozwoju pasmowo-węzłowego.

Wielką rangę w systemie komunikacyjnym Mazowsza ma trasa zwana Wielką Obwodnicą Warszawy lub Dużą Obwodnicą Warszawy (DOW). Składa się ona z odcinków istniejących dróg krajowych o numerach 50 i 62. Trasa omija Warszawę średnio $20-30 \mathrm{~km}$ od granic stolicy i stanowi najważniejszy element rusztu komunikacyjnego wyznaczonego Obszaru Metropolitalnego Warszawy. Ma ona za zadanie obsłużyć ruch tranzytowy w kierunku wschód - zachód, a także w kierunku Via Baltica, zwłaszcza pojazdów ciężkich, których celem nie jest miasto stołeczne.

Lokalizacje miast i miejscowości gminnych na szlaku wielkiej drogowej obwodnicy Warszawy to: Sochaczew, Żyrardów, Mszczonów, Grójec, Góra Kalwaria, Kołbiel, Mińsk Mazowiecki, Łochów, Wyszków, Serock, Zakroczym, Wyszogród. Wszystkie odcinki dróg na omawianej obwodnicy tranzytowej uzyskują w trakcie modernizacji klasę jednojezdniowych lub dwujezdniowych dróg głównych ruchu przyspieszonego. Na szlaku całej DOW powstają obwodnice większych miast i miejscowości. Najważniejsze na jej szlaku węzły drogowe to dwa skrzyżowania z autostradą A2. Jedno z nich funkcjonuje już jako węzeł Wiskitki (w pobliżu 
planowanego centralnego lotniska), drugie (projektowane) w pobliżu Mińska Mazowieckiego stymulować może to miasto do rozwoju gospodarczego. Znaczenie tych dwóch miejsc węzłów wzmacniać będą istniejące linie kolejowe o ważnej roli. Skrzyżowania obwodnicy Warszawy z liniami kolejowymi lub promieniście skierowanymi od Warszawy drogami ekspresowymi nadają miejscowościom jeszcze większe szanse rozwoju gospodarczego. Są to miasta: Wyszków, Łochów, Mińsk Mazowiecki, Góra Kalwaria, Mszczonów, Żyrardów, Sochaczew, Nowy Dwór Mazowiecki oraz małe miejscowości w dużym stopniu rokujące rozwój z racji położenia, jak Chynów i Modlin. Omawiana obwodnica stanowi granicę Obszaru Metropolitalnego Warszawy. Zagrożeniem dla rozwoju transportu publicznego jest za mała ranga drogowa - docelowa trasy, która powinna mieć kategorię drogi ekspresowej na całym jej obwodzie.

Trzecią inwestycją stymulującą uporządkowanie strumieni ruchu wokół Warszawy jest Mała Obwodnica Warszawy, która jako całość istnieje jedynie w planach zagospodarowania przestrzennego. Jej zadaniem miało być połączenie małych miejscowości podwarszawskich, takich jak Brwinów, Piaseczno, Konstancin, Józefów, Sulejówek, Halinów, Wołomin, Radzymin, Legionowo, Łomianki oraz odciążenie Warszawy od ruchu drogowego. Trakt małej obwodnicy biegnie istniejącymi drogami wojewódzkimi oraz zbudowanymi nowymi odcinkami. Najważniejszymi nowymi elementami miały być dwie nowe przeprawy przez Wisłę - na południu w Ciszycy pod Konstancinem i na północy w Kiełpinie, między Łomiankami a Jabłonną. Najpilniejszą inwestycją modernizacyjną trasy Małej Obwodnicy Warszawy jest modernizacja odcinka między Sękocinem a Konstancinem, gdzie wzmożony ruch stymuluje stała rozbudowa chińskiego centrum handlowego w Nadarzynie.

\section{Małe miasta jako cel dla osadnictwa i podróży rekreacyjnych}

Proces przemieszczania się ludności z Warszawy do okolic Warszawy dał początek suburbanizacji na przełomie XIX i XX w. i miał charakter elitarny. Wybierano najpiękniejsze okolice Warszawy i sytuowano tam osady, takie jak Otwock, Konstancin, Milanówek, a następnie nadano im cechy uzdrowisk. Przed II wojną światową powstały miasta ogrody o założeniach urbanistycznych zgodnych z koncepcją Howarda. Od II wojny światowej trzykrotny wzrost ludności miały Kobyłka, Łomianki, Nowy Dwór, Piaseczno, Ząbki, Zielonka. Ponadto wszystkie miasta znajdujące się w odległości 50-60 km od Warszawy odznaczają się dodatnim bilansem ludnościowym.

Cel podróży rekreacyjnych z Warszawy to przede wszystkim okolice piękne przyrodniczo. Miejscowości, w tym miasta położone blisko tych atrakcji, mogą skorzystać rozwijając turystykę. Samorządy wykorzystały dotacje europejskie m.in. rewitalizując starówki małych miast, przyciągające dziedzictwem kulturowym. Obserwuje się jednak, że samorządy rzadko przeznaczają tereny miejskie na funkcję pensjonatowa, czy rozrywkową. Nieśmiałe próby Grodziska Mazowieckiego zbudowania Disneylandu nie doczekały się realizacji. Protesty mieszkańców miast przed ingerencją funkcji rozrywkowych, w tym sportowych są powszechne. 
Miasta przegrywają w rozwoju mieszkalnictwa na rzecz gmin podmiejskich. Tempo przekształceń terenów rolnych najwyższe było w gminach Piaseczno, Raszyn, Prażmów, Lesznowola, Góra Kalwaria. W ostatnich latach studia i plany zawierają wskazówki, aby wykorzystywać opuszczone siedliska wiejskie do nowych celów osadniczych, mieszkalnych i rekreacyjnych. Ten postulat może dotyczyć niestety tylko miejscowości usytuowanych peryferyjnie.

Wzrost zamożności społeczeństwa i co się z tym wiąże standardu zabudowy, skutkuje zmianą charakteru zabudowy w miejscowościach, w których dotychczas dominowały letnie domy. Powstają rezydencje całoroczne, których właściciele okopują się w swoich siedzibach, grodząc dostęp do lasu i zbiorników wodnych. Z jednej strony zapobiega to antropopresji cennych przyrodniczo obszarów, z drugiej powoduje większe zagrożenie degradacją środowiska z powodu całorocznego użytkowania posesji (śmiecie, ścieki). Zapotrzebowanie na bazę pobytową rekreacyjną wzrasta, a wymagania dotyczące standardu i oferowanych funkcji są coraz większe. Niektóre z miejscowości promują imprezy związane z dawnymi wydarzeniami, przyciągające turystów (ogromny sukces rekonstrukcji bitew pod Warszawą np. w Sochaczewie, Modlinie, Raszynie, Radzyminie, ale i dalej od Warszawy np. Ciechanowie). Duże pieniądze z turystyki zaczynają stopniowo odgrywać rolę w zagospodarowaniu przestrzeni. Produkt turystyczny zmienia się, większą rolę odgrywa chęć aktywnego wypoczynku zamiast leżenia nad wodą. Preferowany jest sport, zwiedzanie związane z historia, turystyka przyrodnicza, głównie polegająca na podglądaniu ptaków, np. w dolinach rzek. Wśród celów wyjazdowych z Warszawy coraz większą rolę odgrywa turystyka pobytowa w ośrodkach spa.

Szanse przed rozwojem produktu turystycznego dają: wzrost standardu bazy i możliwość jej wykorzystania w ciągu całego roku, moda na turystykę aktywną i dobre jedzenie spożywane w polecanych restauracjach. Zagrożeniem jest krótkotrwałość sezonu, niepewna pogoda, zły dojazd, korki, brak wyprowadzenia ścieżek rowerowych poza granice Warszawy, zawłaszczanie atrakcyjnej okolicy przez nowych mieszkańców, brak parkingów, zaśmiecenie lasów, zanieczyszczenie wód, konkurencja w postaci tanich lotów do dalekich krajów.

Szansą dla realizacji idei wymiany zadań między Warszawą a obszarem otaczającym, w myśl oczekiwań społecznych obu kategorii mieszkańców, stanowi bogaty zasób atrakcyjnych terenów przyrodniczych pod Warszawą i pięknie odnowionych centrów zabytkowych miasteczek dla turystyki kulturowej i rekreacji. Przełomem dla powstania atrakcyjnych rekreacyjnych celów wyjazdowych z Warszawy było przed laty wybudowanie zbiornika wodnego Zegrze na styku Bugu i Narwi. Niestety, szlak wodny z Warszawy przez Kanał Żerański do Zalewu Zegrzyńskiego nie został udrożniony z różnych względów. Te same względy były powodem braku realizacji zbiorników retencyjnych na południe od Warszawy. Rekreacyjne zagospodarowanie brzegów Wisły (np. takie jak nad Dunajem w okolicach Wiednia) napotyka na protesty ekologów. 
Trasy wyjazdowez Warszawy, najbardziejpopularne, które poleca Nawigator Turystyczny [Kaliński 2005], to po prawej stronie Wisły, poza Zalewem Zegrzyńskim, trasa wzdłuż Wisły przez Modlin, Zakroczym do Białobrzegów, nad Bug w okolice Wyszkowa, do Radzymina i Ossowa (Bitwa Warszawska 1920 r.), do Otwocka, Świdra i lasów celestynowskich oraz do Wilgi. Po lewej stronie Wisły celem wyjazdów są liczne ośrodki w Chojnowskim Parku Krajobrazowym wraz z Górą Kalwarią i zamkiem w Czersku, Piaseczyńska Kolejka Wąskotorowa, Mszczonów z gorącymi źródłami termalnymi, Kampinos, Żelazowa Wola, Niepokalanów.

\section{Wizerunek miast}

Wizerunek miejscowości lub ich okolic odgrywa istotną rolę w podejmowaniu decyzji lokalizacyjnych (wybór miejsca zamieszkania, spędzenia urlopu lub podjęcia inwestycji gospodarczej). Pozytywny wizerunek wpływa na zbiór dodatnich skojarzeń, co jest podstawą budowania przewagi w grze konkurencyjnej. Obserwacje wskazuja że dobre skomunikowanie z Warszawą jest najważniejsze dla wszystkich celów wyboru miejsca. Drugim elementem jest wizerunek, na który wpływ ma tożsamość wizualna miasta, jego miejsca publiczne, mieszkańcy (przyjęte normy zachowań i postaw, inicjatywy lokalne), władze lokalne (polityka czynszowa, oferty terenów itp.), massmedia (wzory zagraniczne zagospodarowania przestrzeni, standardu detalu architektonicznego, sposobu zagospodarowania terenu, w tym nawierzchni ulic i placów, możliwość aranżacji zieleni, efektowne uprawy indywidualnych ogródków). Dobry wizerunek daje prestiż miejscu, co ściąga wartościowe warstwy społeczne i zachęca młode kadry do pozostania. Dysharmonia i nieład przestrzenny są zagrożeniem dla rozwoju miasta i odstraszają inwestorów oraz nowych mieszkańców lub turystów.

Cechy układu funkcjonalno-przestrzennego wpływają na możliwość aranżacji przestrzeni publicznych. Układy historyczne miast, wywodzące się ze średniowiecza z rynkiem i ratuszem pośrodku miasta, dają większą możliwość koncentracji działań rewitalizacyjnych i rozwoju usług. Miasta z tego rodzaju układami urbanistycznymi na Mazowszu mają największe szanse na poprawę wizerunku. Budowa obwodnic dla tranzytu uwalnia strefę rynku lub główną ulicę - deptak od uciążliwości komunikacyjnych. W Garwolinie założonym w 1407 r. wojna zniszczyła centrum, lecz powojenna odnowa głównego rynku $\mathrm{z}$ przyległościami odbyła się $\mathrm{w}$ duchu zachowania atmosfery małego miasta $\mathrm{z}$ ochroną i ekspozycją wartościowych zabytków (w czym pomógł Wydział Architektury Politechniki Warszawskiej - H. Adamczewska, K. Weichert). Podobny proces miał miejsce w Radomiu i Makowie Mazowieckim, z tym, że cenne obiekty - zabytki kultury żydowskiej nie są tam do dziś odnowione, podobnie jak w Górze Kalwarii i Tarczynie, gdyż nie mają jasnego statusu własnościowego. W Pułtusku najdłuższy w Europie rynek jest największą atrakcją niezniszczonego podczas wojny miasta. W Górze Kalwarii układ przestrzenno-funkcjonalny ma formę pochodną od teoretycznej koncepcji miasta kultu religijnego - Nowej Jerozolimy w kształcie krzyża. Do dzisiejszych czasów zachował się w części dawny barokowy układ 
przestrzenny. Struktura ta wypełniona jest zabudową małomiasteczkową niejednorodnej wartości. Unikatowe położenie na skarpie wiślanej, bliskość pozostałości zamku w Czersku, przeprawa drogowa i kolejowa przez Wisłę predestynują Górę Kalwarię do grona miast, które mają największe szanse wszelkiego rodzaju rozwoju. Przykłady te i inne pokazują jak wielką wartość miała możliwość zagospodarowania najważniejszych części miast historycznych zabudową integracyjna, stworzoną przez dobrych projektantów. Obecnie brak jest takich możliwości w zastanych formach osadnictwa, ale nowe lokalizacje różnego rodzaju i próby przebudowy istniejących, powinny podlegać wypróbowanym zasadom organizacji przestrzennej.

Wielbiciele idei miast ogrodów zapominali o ukształtowaniu przestrzeni wspólnych dla celów społecznych. Nawet, jeśli w założeniach miejsca takie w planach się znajdowały, to później były zdegradowane i zagospodarowane w inny sposób. Obecnie miejsca publiczne w nomenklaturze projektantów to tylko ulice i place dla komunikacji. Niedawno na forum zorganizowanym w związku z lokalnymi inwestycjami w ramach budżetu partycypacyjnego w Garwolinie, uczestnik postulował, aby w centrum miasta powstał park z wierzbą i kaczkami.

Wszelkie publikowane badania dotyczące małych miast w Polsce omijają starannie problematykę wizerunku, skupiając się na statystykach, czego przyczyną mogą być trudności z uchwyceniem przyczyn takiego lub innego postrzegania miejsca. Chaos przestrzenny miast może brać się także z kompleksów z powodu braku wartościowego dziedzictwa materialnego, co daje większą władzę konserwatorom zabytków niskiej klasy nad urbanistami. Inna, ważną przyczyną niedoceniania dobrego wizerunku miasta przez władze jest brak krytyki urbanistycznej i niedostateczne wymagania wobec nowych projektów. Rzadko można spotkać w urzędach gminnych studia urbanistyczne nad sposobem wpasowania nowej inwestycji w krajobraz z pozycji przechodnia.

Złe postrzeganie wyglądu miast mazowieckich, w tym w aglomeracji warszawskiej uznawanej przez wielu jako trzeci świat, może być przyczyną poszukiwania poza miastami lokalizacji pod miejsca zamieszkiwania lub turystykę. Dla tej ostatniej, lokalizacje pod całoroczną zabudowę pensjonatową dobrych standardów, wyznaczone w lokalnych dokumentach planistycznych miast nie zdarzają się często, a przecież byłyby to miejsca znacznie bezpieczniejsze dla użytkowników niż na pustkowiu. Forma miejska odpowiednio wykształcona jest najlepszą strukturą funkcjonalno-przestrzenną do zamieszkiwania.

\section{Wartość historyczna dziedzictwa kulturowego i rewitalizacja miast}

Znacząca rola w historii kraju regionu mazowieckiego, głównie dzięki spławności Wisły, spowodowała powstanie bogactwa kulturowego, które widoczne jest w zagospodarowaniu przestrzennym. Zabudowa miast, miasteczek i ośrodków osadniczych rozciągała się wzdłuż szlaków wodnych i drogowych, a następnie dopiero kolejowych prowadzących do Warszawy. 
Wiele miast na Mazowszu ma genezę historyczną. Do miast, w których oprócz układu urbanistycznego przetrwały w centrum zespoły zabytkowe należą przede wszystkim miasta nadwiślańskie takie jak: Płock, Nowy Dwór Mazowiecki, Warszawa, Góra Kalwaria, a także miasta położone nad Bugiem i Narwią oraz ich dopływami (Pułtusk, Maków Mazowiecki, Siedlce). W miastach przy szlakach drogowych także zachowało się cenne dziedzictwo materialne nadające się do rewitalizacji, m.in. w Szydłowcu, Przasnyszu i w innych miastach.

Rewitalizacja miast dofinansowana przez UE dotyczyć miała w założeniach dzielnic o zdegradowanej zabudowie mieszkaniowej, poprzemysłowej, powojskowej i pokolejowej. Lokalne programy rewitalizacji struktur miejskich winny były objąć aspekty społeczne, ekonomiczne, techniczne, przestrzenne, ekologiczne i urbanistyczno-architektoniczne. Rewitalizacja miast miała wzmacniać znaczenie walorów miast, poprzez preferencje dla stref zabudowy zabytkowej zapobiegać rozlewaniu się zabudowy i degradacji centrów miejskich.

Dokonane działania rewitalizacyjne obszarów staromiejskich dotyczyły uzupełnień i modernizacji infrastruktury technicznej, elewacji budynków w pierzejach rynków, w tym budowli użyteczności publicznej, remontów dachów i klatek schodowych, zmian w zagospodarowaniu terenu, nawierzchni ulic i placów. Ponadto podejmowano zadania inne, takie np. jak w Tarczynie - wybudowanie w mieście budynku komunalnego do przekwaterowań lokatorów zdegradowanych kamieniczek w rynku, które miały być poddane rewitalizacji. Miasto to zaangażowało autorytet $\mathrm{w}$ dziedzinie odnowy zespołów mieszkalnych - prof. Macieja Chmielewskiego - do opracowania, w ramach ćwiczeń projektowych, wariantów koncepcji najstarszej pierzei rynku. Najwięcej dokonań służących poprawie prestiżu wizerunkowego miasta miało miejsce w Płocku i Żyrardowie.

Poza centrum miast rewitalizacją objęto obszary zieleni nadrzecznych, obiekty sportowe i co najważniejsze, najcenniejsze zabytki odległe od centrum miasta, jak np. podjęto renowację elewacji zamku w Szydłowcu czy odnowę budynku zespołu zabytkowych koszar w Górze Kalwarii w celu wykorzystania obiektu na funkcje publiczne. Powszechne było ocieplanie budynków osiedli miejskich.

Lokalne programy rewitalizacji, na skutek nacisków zainteresowanych, nie uniknęły najczęściej powtarzanego błędu, jak nadmierne rozproszenie zadań w mieście. Obecnie głównym narzędziem działania, wg ustawy o rewitalizacji z 2015 r., będzie partycypacja społeczna.

W warunkach polskich wieloletnie zaniedbania wymagaja, aby wieloaspektowa rewitalizacja trwała jako proces ciagły wiele lat, przy ogromnych środkach finansowych. Oczywiście oprócz środków, operacje rewitalizacji wymagają niezwykłych umiejętności organizacyjnych, których w miastach mazowieckich trudno się dopatrzeć. Odgrywają tutaj role też mniejsze możliwości techniczne, wynikające z gorszej jakości technicznej ocalałej zabudowy niż w innych częściach Polski. 


\section{Walory i zagrożenia środowiska przyrodniczego}

W większejodległości od Warszawy, poza delimitacjąOMW, chronione są kompleksy leśne Puszczy Kamienieckiej (Nadbużański Park Krajobrazowy), Puszczy Kozienickiej (Kozienicki Park Krajobrazowy), lasy Puszczy Bolimowskiej (Bolimowski Park Krajobrazowy). Tereny te cieszą się coraz większym zainteresowaniem, gdyż systematyczna utrata resztek zieleni w obrębie OMW skłania zainteresowanych lokalizacją osadnictwa w pięknym krajobrazie i zajmowaniem terenów pod różne funkcje poza jego granicami. Korzystne byłoby przeobrażanie terenów siedlisk wiejskich, o zanikającej funkcji rolniczej, pod całoroczną zabudowę turystyczną lub osiedleńczą niezwiązaną z rolnictwem zamiast zawłaszczania terenów otwartych. W ten sposób udałoby się zachować cenne układy ruralistyczne wsi wyludniających się. Największym powodzeniem, wśród terenów odległych więcej niż $60 \mathrm{~km}$ od Warszawy, od lat cieszy się Dolina Bugu (Rybienko Leśne, Brańszczyk, Brok) i Narwi, na co korzystnie wpływa malowniczy kurpiowski rejon etnograficzny i piękne, zadbane miasto Pułtusk.

Niekontrolowane rozlewanie się zabudowy w obrębie OMW skutkuje kurczeniem się obszarów zieleni i przerywaniem zielonego pierścienia wokół Warszawy. Szanse na stworzenie obszaru chronionego otaczającego aglomerację warszawska, któremu będzie przysługiwać odrębne prawo ochronne dla krajobrazu jeszcze istnieja, choć opieszałość decyzji w tym zakresie jest bardzo niekorzystna. Obecnie ochrona prawna przyrody wewnątrz pierścienia obejmuje jedynie jego najcenniejsze fragmenty, takie jak obszary puszczy kampinoskiej (Kampinoski Park Narodowy), lasy otwockie i celestynowskie (Mazowiecki Park Krajobrazowy), lasy chojnowskie (Chojnowski Park Krajobrazowy) oraz doliny rzek Wisły, Narwi i Bugu stanowiące obszary chronione Natura 2000, kompleksy leśne pozostałości dawnych puszcz chronione pod nazwą Bolimowskiego Parku Krajobrazowego. Ponad wymienione w obrębie pierścienia wokół Warszawy znajdują się obszary pięknych krajobrazów podwarszawskich znane i cenione od lat. Nie są one skuteczne chronione przed antropopresja głównie z powodu niejednoznaczności przepisów. Miejscowości podmiejskie powstałe w lesie (cała linia otwocka i częściowo linie konstancińska, milanowska oraz gmina Lesznowola, Zalesie, Legionowo) tracą charakter leśny, a założenie pierwotne w postaci luźno rozrzuconych domów w lasach nie wymagało niegdyś wyposażenia we wspólną przestrzeń publiczna, $\mathrm{w}$ tym wspólną zieleń. Te pierwotne założenia miast ogrodów są jedną z głównych przyczyn bezładu przestrzennego większości tych miejscowości. Drugą ważną wadą idei miast ogrodów jest zbyt łatwa utrata drzewostanu na pierwotnie leśnych działkach na skutek dokonywania wtórnej parcelacji działek.

\section{Regulacje planistyczne}

Pierwsze koncepcje planistycznej regulacji rozwoju aglomeracji [Różański 1929] były odpowiedzią na bezplanowy proces gwałtownej parcelacji terenów niszczący powierzchnie leśne i walory krajobrazowe. Aby zahamować proces rozlewania się aglomeracji wyznaczono 
zielony pierścień wokół terenów zabudowanych. Dziś słusznie wraca się do tej koncepcji, która mogłoby ograniczyć wciskanie się zabudowy w piękny krajobraz i urealnić ideę wzajemnej wymiany usług między mieszkańcami Warszawy a mieszkańcami sąsiednich gmin. Warunkiem skuteczności działania wszelkich sposobów ograniczania zawłaszczania terenów przyrodniczych jest objęcie obszaru pierścienia prawną ochroną. Zagrożeniem dla harmonijnego zrównoważonego rozwoju okolic Warszawy jest brak wspólnego planu OMW.

Wśród lokalnych podwarszawskich walorów przyrodniczych i gospodarczych istnieje tradycja związana z umiejętną produkcją żywności dla Warszawy i okolic. W grójeckim sadownictwo, w okolicach Karczewa wędliny, pod Jabłonną nowalijki i chryzantemy pod szkłem, w okolicach Ożarowa warzywa gruntowe. Obecnie pod rozwój osadnictwa i gospodarki przeznacza się najcenniejsze obszary tradycyjnych upraw sadowniczych niechronionych prawnie.

Wielkim zagrożeniem dla tożsamości małych miast znajdujących się w granicach wyznaczonego Obszaru Metropolitalnego Warszawy jest koncentracja handlu i usług w formach o przekroczonej skali. W okolicach Lesznowoli i Nadarzyna rozwija się gigantyczna strefa tzw. Centrum Chińskiego. Wybudowanie stadionu narodowego na miejscu stadionu dziesięciolecia w Warszawie spowodowało przeniesienie się Jarmarku Europa w miejsce pod Nadarzynem. Niefortunne usytuowanie centrum chińskiego zagraża nie tylko funkcji handlu i usług w miastach, w tym w Warszawie (patrz zanik handlu na ulicach dojazdowych, np. Grójeckiej), lecz także zagrożenie dla okolicznej przyrody, gdyż omawiany obszar znajduje się w planowanym zielonym pierścieniu wokół aglomeracji warszawskiej.

Analiza studiów uwarunkowań i kierunków zagospodarowania przestrzennego gmin w Obszarze Metropolitalnym Warszawy wykazała nadmierny zakres wyznaczonego terenu pod mieszkalnictwo i usługi. Autorzy badania, powołując się na prognozę demograficzną GUS dla 2030 r. wyliczyli dwukrotne przekroczenie rozmiaru tego obszaru dla prognozowanej liczebności populacji [opracowanie własne - Mazowieckiego Biura Planowania Regionalnego - opublikowane w Studium Planu Zagospodarowania Przestrzennego OMW, 2010]. Autorzy zastrzegają jednakże, że niejednolite metody sporządzania studiów gminnych nie zawsze pozwalają na wyodrębnienie funkcji usługowych od mieszkaniowo-usługowych.

\section{Literatura}

Bański J., Czapiewski K.Ł., Mazur M., Policentryczność rozwoju Mazowsza, 2012, Mazowsze Studia Regionalne, 10, MBPR, Warszawa, s. 71-88.

Chmielewski J.M., 2002, Koncepcja rozwoju aglomeracji warszawskiej a jej stan obecny, [w:] Osiagnięcia i perspektywy warszawskiego środowiska urbanistów i planistów przestrzennych (u progu 80-lecia TUP), Oddział Warszawski TUP, s. 58-73. 
Chmielewski J., Syrkus S., 2013, Warszawa funkcjonalna. Przyczynek do urbanizacji regionu warszawskiego, SARP, Warszawa.

Kochanowska D., Kochanowski M, 2012, W strone miasta, Wyższa Szkoła Ekologii i Zarządzania, Warszawa.

Kochanowski M., 2005, Suburbanizacja - dezurbanizacja - reurbanizacja. Refleksje po konferencji Problemy Suburbanizacji, Urbanista, 11, s. 39-40.

Kolej w Warszawie i Województwie Mazowieckim, 2017, Stowarzyszenie Integracji Stołecznej Komunikacji, Internet.

Mała Obwodnica Warszawy, 2017, Stowarzyszenie Integracji Stołecznej Komunikacji, Internet.

Plan Zagospodarowania Przestrzennego Województwa Mazowieckiego, 2004, Mazowieckie Biuro Planowania Przestrzennego i Rozwoju Regionalnego, Warszawa.

Studium Planu Zagospodarowania Przestrzennego Obszaru Metropolitalnego Warszawy, 2010, MBPR, Warszawa.

Studium Uwarunkowań i Kierunków Zagospodarowania Przestrzennego Warszawy, 2006, Urząd Miasta Stołecznego Warszawy, Warszawa.

Sumień T. i in., 2009, Podstawy rozwoju małych miast w Polsce-diagnoza-prognoza-synteza stanu istniejacego i zamierzonego, Instytut Gospodarki Przestrzennej i Mieszkalnictwa, Warszawa.

Śleszyński P., 2012, Warszawa i Obszar Metropolitalny Warszawy a rozwój Mazowsza, Seria Trendy Rozwojowe Mazowsza, 8, MBPR, Warszawa.

Topczewska T., Bartoszewicz D., Donimirska K., W. Siemiński, 2005, Rewitalizacja miast, Instytut Gospodarki Przestrzennej i Mieszkalnictwa, Warszawa. 


\section{The variable fate of the settlement network of the Mazovia region (including the Warsaw Metropolitan Area)}

\section{ABSTRACT}

The economic development of Warsaw, the Polish and Mazovian capital, results in its spatial development. The nature of the latter development is not correct when on the outskirts of the capital city and outside its borders there is an agglomeration zone not covered by planned urbanization. The growth of the agglomeration without a plan poses a threat to the identity of the small towns it encompasses. The next great threat is underdeveloped integrated public transport, especially rail-based services, serving to connect Warsaw and the agglomeration, especially in its southern part. In order to stop the process of agglomeration sprawl, a green ring should be designated around the Warsaw agglomeration, so as to limit the scope at which new buildings gradually replace a beautiful landscape and to make real the concept of mutual exchange of services between the residents of Warsaw and the neighboring municipalities. An opportunity for the implementation of this concept through cultural tourism and recreation is provided by the large number of attractive natural areas near Warsaw and beautifully renovated centers of historical towns.

Key words: Mazovia region, Warsaw Metropolitan Area, settlement network, suburbanization, rail transport, road beltways, image of the city, cultural heritage and urban renewal, the natural environment

Prof. arch. dr hab. Mieczysław Kochanowski, prof. zwyczajny Wyższej Szkoły Ekologii i Zarządzania, ul. Olszewska 12, Warszawa, em. prof. Politechniki Gdańskiej, były dziekan Wydziału Arch. PG, były prezes Zarządu Głównego TUP, były członek GKUiR, były członek Państwowej Rady Gospodarki Przestrzennej, były dyrektor Zespołu Planowania Regionalnego w Komisji Planowania przy Radzie Ministrów.

Professor Arch., PhD Mieczysław Kochanowski, Ordinary Professor of the University of Ecology and Management, Professor emeritus of the Gdansk University of Technology, former dean of the Faculty of Architecture of the Gdansk University of Technology, former President of the Society of Polish Town Planners, former member of GKUiR, former member of the State Council for Spatial Management, former director of the Regional Planning Team in the Planning Committee of the Council of Ministers.

Mgr inż. arch. Katarzyna Donimirska, autorka projektów architektonicznych i planów zagospodarowania przestrzennego prowadząca ćwiczenia projektowania przestrzennego w Wyższej Szkole Ekologii i Zarządzania, ul. Olszewska 12, Warszawa. Była wieloletnia pracownica Instytutu Gospodarki Przestrzennej i Mieszkalnictwa w Warszawie .

MSc Arch. Katarzyna Donimirska, the author of architectural designs and spatial development plans, the instructor of spatial design courses at the University of Ecology and Management, a long-time employee of the Institute of Spatial Management and Housing in Warsaw. 